Research Article, Issue 2
Analytical Methods in Environmental Chemistry Journal
JMECJ

\title{
Food Analysis: Task specific ionic liquids for separation of nickel and cadmium from olive oil samples by thermal ultrasound-assisted dispersive multiphasic microextraction
}

\author{
Aisan Khaligh ${ }^{\mathrm{a}}$ \\ ${ }^{a}$ Department of Chemistry, Bilkent University, Ankara, Turkey
}

A R T I C L E I N F O:

Received 17 March 2019

Revised form 4 May 2019

Accepted 25 May 2019

Available online 20 Jun 2019

Keywords:
Olive oil
Cadmium and nickel
Thermal ultrasound-assisted
dispersive multiphasic
microextraction
Task specific ionic liquid
Atom trap flame atomic
absorption spectrometry

\begin{abstract}
A B S T R A C T
In this study, a novel task-specific ionic liquid (TSILs) was used for highly sensitive extraction and separation of nickel and cadmium in olive oil by thermal ultrasound-assisted dispersive multiphasic microextraction (TUSA$\mathrm{DMP} \mu \mathrm{E})$. By proposed method, a mixture containing of hydrophilic TSILs ( $\alpha$ - Cyano-4-hydroxycinnamic acid diethylamine; [CHCA] [DEA] and 1-(2-Hydroxyethyl)-3-methylimidazolium tetrafluoroborate; [HEMIM] [BF4]) as a complexing and extracting solvent, acetone as a dispersant of TSILs was added to diluted olive oil with n-hexane containing Cd (II) and $\mathrm{Ni}$ (II) that was already complexed by TSILs in $60^{\circ} \mathrm{C}$ at $\mathrm{pH}$ 6.0-7.5. After optimized conditions, the enrichment factor (EF), Linear range (LR) and limit of detection (LOD) were obtained $(19.3 ; 19.6)$, (5.0- $415 \mu \mathrm{g} \mathrm{L}^{-1} ; 2.7$ $\left.92 \mu \mathrm{g} \mathrm{L}^{-1}\right)$ and $\left(1.3 \mu \mathrm{g} \mathrm{L}^{-1} ; 0.6 \mu \mathrm{g} \mathrm{L}^{-1}\right)$ with [CHCA] [DEA] and (13.7; 14.2), (7.5- $\left.600 \mu \mathrm{g} \mathrm{L}^{-1} ; 3.6-128 \mu \mathrm{g} \mathrm{L}^{-1}\right)$ and $\left(2.2 \mathrm{ng} \mathrm{L}^{-1} ; 0.9 \mu \mathrm{g} \mathrm{L}^{-1}\right)$ with [HEMIM][BF4] for $\mathrm{Ni}$ and $\mathrm{Cd}$ ions in olive oil samples respectively. In addition, the ions extraction with [CHCA] [DEA] is more efficient than [HEMIM] [BF4] by TUSA-DMP $\mu$ E method (less than $60 \%$ ). Moreover, the validation of methodology was achieved by standard oil by microwave digestion/ETAAS technique and spike samples with atom trap flame atomic absorption spectrometry (AT-FAAS)
\end{abstract}

\section{Introduction}

The edible oil toxicity by cadmium $(\mathrm{Cd})$ and nickel (Ni) ions is very important problem in food industry because of bioaccumulation in human body and cause damage to organs such as kidney dysfunction, hypertension, liver damage, lung damage, cancer and adverse DNA modifications [1-3]. The presence of high concentration of $\mathrm{Cd}$ (II) and $\mathrm{Ni}$ (II) in edible oils may also have deleterious effects on the quality of the product, causing changes to their taste and smell [4]. Cd (II) and Ni (II) ions are easily transferred from arable land to oil plants, Corresponding Author: Aisan Khaligh

Email: akhalighv@gmail.com https://doi.org/10.24200/amecj.v2.i2.64 which are increasingly contaminated by cadmium and nickel from phosphate-based fertilizers. These toxic elements can also be present in edible oils, as a result of contamination from the environment, the refining process, the storage tank, and the packing with different materials [5-7]. The U.S. Food and Drug Administration (USFDA) reported that the permissible limits of nickel and cadmium in the vegetables oils are less than $1.0 \mathrm{mg} / \mathrm{kg}$ and $0.1 \mathrm{mg} /$ $\mathrm{kg}$, respectively. For healthy people, the mean of cadmium and nickel concentration in human serum samples is less than $0.2 \mu \mathrm{g} \mathrm{L}^{-1}$. Therefore, the accurate determination of trace cadmium and nickel ions in edible oils is an important concern because 
of their toxic role in human body and possibilities for adulteration detection and oil characterization [8-10]. The presence of trace metal ions in edible oils were quantitatively determined by different techniques such as flame atomic absorption spectrometry (F AAS) [1, 3, 11], electro-thermal atomic absorption spectrometry (ET AAS) [12], inductively coupled plasma atomic emission spectrometry (ICP AES) [12, 13], inductively coupled plasma mass spectrometry (ICP MS) [4, 14], and adsorptive stripping square wave voltammetry (Ad SSWV) [15]. Sample preparation is a critical step in the whole analytical procedure due to low concentration levels of metal ions and high organic matrix of oils [3, 16]. Moreover, many of conventional methods employed for the sample pretreatment such as acid digestion, wet or dry ashing of oil matrix, closed-vessel, and focused open-vessel microwave dissolution, dilution as well as basic alcoholic solubilization are not recommended because of associated safety hazards, a potential risk of sample contamination, analyte losses and being time-consuming [17]. In this regard, preconcentration and separation steps are required prior to analyte determination. Recently, dispersive liquid-liquid microextraction (DLLME) has introduced by Rezaee et al [18] has gained increasing popularity for the trace metal ions preconcentration-separation in food and biological samples because of its simplicity, rapidity, low cost, low consumption of toxic organic solvents as well as the high preconcentration factor and extraction efficiency that are achieved [19, 20]. DLLME uses an extraction solvent, immiscible in the aqueous phase, and a disperser solvent, miscible in both the extraction solvent and in the aqueous sample solution. In this method, the contact area between the extraction solvent and the sample solution is extremely large, so the extraction equilibrium is reached rapidly. In the DLLME, the choice of the appropriate mixture of the extraction and dispersive solvents is critical for achieving high enrichment factor [21]. Ionic liquids (ILs), as an alternative to traditional organic solvents in sample preparation, are one of the mostly considered extraction solvents in DLLME due to their low volatility, high viscosity, dual natural polarity, good thermal stability, and miscibility with water and organic solvents (TSIL1,chempaper) without requiring a dispersive solvent $[20,22,23]$. It has been demonstrated that organic analytes can be partitioned to ILs based on the hydrophobicity of the analytes and ILs, but metal ions cannot be extracted in liquid/liquid systems owing to negligible partitioning and the tendency of metal cations to remain hydrated in the aqueous phase [21]. Therefore, it is necessary to use chelating agents which firstly form hydrophobic complex with metal ions, and then the formed complex extract into extraction solvent. In recent years, task specific ionic liquid (TSIL), a new group of ionic liquids, has been introduced in which thiol or urea groups are covalently attached to the cationic or ionic impart of the IL. TSIL can be used as a dispersive and extraction solvent for metal ions in DLLME method without any chelating agents [23]. In the TSIL-DLLME, extraction and complexation of metal ions were done simultaneously and this newly developed procedure is a very fast and easy single-step method without needing chelating agents compared to the traditional DLLME method [24]. To date, different DLLME modes based on the ILs have been developed such as temperature controlled, ultrasonic-assisted, microwave-assisted and vortex-assisted [25]. Zhou et al. made the most preferred modifications in IL-DLLME which are ultrasound-assisted (US) and temperaturecontrolled (TC) techniques [26, 27]. In TC, ILdispersive liquid-liquid microextraction, the extraction solvent is heated until it is completely solubilized in the water matrix. The heating improves the mass transfer of the analyte to the IL [28]. In US, IL-dispersive, liquid-liquid microextraction, ultrasound and dispersive solvents are used to increase the extraction ability of ILs [28]. The motivation behind the present work is that a great number of the TSIL-DLLME analytical procedures reported to date have dealt with water analysis or relatively simple matrices. For example, Werner developed TSIL-USA-DLLME combined 
with liquid chromatography for preconcentration and determination of $\mathrm{Cd}$ (II), $\mathrm{Co}$ (II) and $\mathrm{Pb}$ (II) ions in tea samples [22]. However, application of this method in edible oil samples has not been studied yet. Therefore, the main aim of the current study is to develop a simple, rapid, reliable and economic method for the determination of trace $\mathrm{Cd}^{2+}$ and $\mathrm{Ni}^{2+}$ ions in olive oil samples without chelating agents. This method is based on the combination of the thermal ultrasoundassisted-task specific ionic liquid-dispersive multiphasic microextraction technique (TUS-TSIL-DMP $\mu \mathrm{E}$ ) and ATFAAS. In the present approach, two hydrophilic TSILs, ([CHCA] [DEA]) and [HEMIM][BF4]), were used and compared not only as an extraction solvent but also as a selective chelating agent. Experimental parameters including sample $\mathrm{pH}$, amount of sorbent, sample volume, eluent type and volume, and time of ultrasound, etc., have been studied and optimized.

\section{Experimental procedure}

\subsection{Apparatus}

The measurements of $\mathrm{Cd}$ (II) and $\mathrm{Ni}$ (II) ions were performed with a spectra GBC 906 double beam atomic absorption spectrophotometer equipped with atom trap, air-acetylene flame and ultra-pulse deuterium as a background correction (AT-FAAS, GBC, Model; Plus 906, Australia). The atom trap was installed on an air-acetylene burner. A data station (AT-compatible computer) with 906 AAS operating software was utilized for collecting and storing data. For the matter of interest, the operating parameters were set as recommended by the manufacturer. A Cd and Ni hollow cathode lamps as the radiation sources were used at a current of $10 \mathrm{~mA}$ and $3 \mathrm{~mA}$, and a wavelength of $279.5 \mathrm{~nm}$ and $228.8 \mathrm{~nm}$, respectively, with a spectral bandwidth of $0.5 \mathrm{~nm}$. The $\mathrm{pH}$ values of the solutions were measured by a Metrohm $\mathrm{pH}$-meter (model 744, Herisau, Switzerland) supplied with a glass-combined electrode. Phase separation was carried out by a Demerd centrifuge (model LC812). A Kunshan ultrasonic bath with temperature control (model KQ-100DE, Kunshan, China) was used throughout this study.

\subsection{Chemical Reagents and Material}

A standard stock solutions $\left(1000 \mathrm{mg} \mathrm{L}^{-1}\right)$ of $\mathrm{Ni}$ (II) and Cd (II), $\alpha$ - Cyano- $\varepsilon$-hydroxycinnamic acid diethylamine ([CHCA] [DEA]) ionic liquid, acetone, sodium tetrafluoroborate $\left(\mathrm{NaBF}_{4}\right)$, ethyl acetate, chloroethanol, 1-methylimidazole and all of the other chemical compounds and reagents were of analytical grade and purchased from Merck (Darmstadt, Germany). Ultra-pure deionized

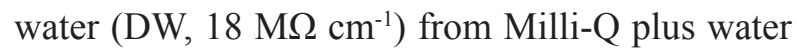
purification system (Millipore, Bedford, MA, USA) was used for preparing all aqueous solutions. The standard and experimental solutions of $\mathrm{Ni}^{2+}$ and $\mathrm{Cd}^{2+}$ were prepared daily by appropriate dilution of the stock solutions with DW. The $\mathrm{pH}$ adjustments of samples were made using appropriate buffer solutions including sodium acetate $\left(\mathrm{CH}_{3} \mathrm{COONa} /\right.$ $\left.\mathrm{CH}_{3} \mathrm{COOH}, 1-2 \mathrm{~mol} \mathrm{~L}^{-1}\right)$ for $\mathrm{pH} 3.8-5.8$, sodium phosphate $\left(\mathrm{Na}_{2} \mathrm{HPO}_{4} / \mathrm{NaH}_{2} \mathrm{PO}_{4}, 0.2 \mathrm{~mol} \mathrm{~L}-1\right)$ for $\mathrm{pH}$ of 5.8-8.0, and ammonium chloride $\left(\mathrm{NH}_{3} /\right.$ $\mathrm{NH}_{4} \mathrm{Cl}, 0.2 \mathrm{~mol} \mathrm{~L}^{-1}$ ) for $\mathrm{pH} 8-10$. All the laboratory glassware and plastic tubes were cleaned by soaking in $10 \%(\mathrm{v} / \mathrm{v})$ nitric acid for at least $24 \mathrm{~h}$ and then rinsed several times with deionized water and dried in a clean oven prior to use. In this study, five olive oils (Cooking and skin) was selected and used for investigation.

\subsection{Synthesis of TSIL}

The hydrophilic TSILs, $(\alpha-$ Cyano-4hydroxycinnamic acid diethylamine; [CHCA] [DEA] purchased from Merck and [HEMIM] [BF4] was prepared according to the synthesis method [27]. The general procedure for synthesis of [HEMIM][BF4] TSIL is described as follows: First, $13.9 \mathrm{~g}$ (0.169 mol) of 1-methylimidazole (99 $\%$ ), distilled over $\mathrm{KOH}$, was slowly added to 15.0 $\mathrm{g}(0.186 \mathrm{~mol})$ of freshly distilled 2-chloroethanol in a round-bottomed flask equipped with a magnetic stirrer and a condenser, under nitrogen atmosphere. The mixture was refluxed at $100^{\circ} \mathrm{C}$ for $4 \mathrm{~h}$. After cooling to $70^{\circ} \mathrm{C}$, the reaction mixture was washed four times with ethyl acetate, and then dried in vacuo at $70{ }^{\circ} \mathrm{C}$ for $8 \mathrm{~h}$. The product, 1-(2- hydroxyethyl)-3methylimidazolium chloride ([HEMIM][Cl]), was 
obtained in form of white crystalline solid (65\% yield, $17.9 \mathrm{~g})$. This compound was characterized by $1 \mathrm{H} \mathrm{NMR} \mathrm{(500} \mathrm{MHz,} \mathrm{D}_{2} \mathrm{O}, 25^{\circ} \mathrm{C}, \delta$; ppm). The obtained data are here: $3.87(3 \mathrm{H}, \mathrm{S}, \mathrm{NCH} 3), 3.89$ $\left(2 \mathrm{H}, \mathrm{t}, \mathrm{NCH}_{2} \mathrm{CH}_{2} \mathrm{OH}\right), 4.28\left(2 \mathrm{H}, \mathrm{t}, \mathrm{NCH}_{2} \mathrm{CH}_{2} \mathrm{OH}\right)$, $7.42(1 \mathrm{H}, \mathrm{d}, \mathrm{H}-4), 7.47(1 \mathrm{H}, \mathrm{d}, \mathrm{H}-5)$, and $8.71(1 \mathrm{H}$, $\mathrm{S}, \mathrm{H}-2)$.

Then $30.0 \mathrm{~g}(0.185 \mathrm{~mol})$ of [HEMIM][Cl] was reacted with $26.4 \mathrm{~g}(0.24 \mathrm{~mol})$ of $\mathrm{NaBF}_{4}$ in acetonitrile solvent at room temperature for $48 \mathrm{~h}$, under nitrogen atmosphere. The reaction mixture was then cooled to $18{ }^{\circ} \mathrm{C}$ overnight and filtered through a short column of Celite to remove $\mathrm{NaCl}$. The solvent was removed using a rotary evaporator, and the residual chloride test (a concentrated $\mathrm{AgNO}_{3}$ solution test) performed on product was negative. The product, I-(T-hydroxyethyl)-rmethylimidazolium tetrafluoroborate ([HEMIM] [BF4]), was obtained as a viscous material (62\% yield). Karl Fischer test showed $<100$ ppm of water and the absence of chloride ion confirmed the product purity $(>99.5 \%)$. This compound was also characterized by $1 \mathrm{H}$ NMR $\left(500 \mathrm{MHz}, \mathrm{D}_{2} \mathrm{O}\right.$, $25^{\circ} \mathrm{C}, \delta$; ppm): $3.83(3 \mathrm{H}, \mathrm{S}, \mathrm{NCH} 3), 3.87(2 \mathrm{H}, \mathrm{t}$, $\left.\mathrm{NCH}_{2} \mathrm{CH}_{2} \mathrm{OH}\right), 4.24\left(2 \mathrm{H}, \mathrm{t}, \mathrm{NCH}_{2} \mathrm{CH}_{2} \mathrm{OH}\right), 7.38$ $(1 \mathrm{H}, \mathrm{d}, \mathrm{H}-4), 7.43(1 \mathrm{H}, \mathrm{d}, \mathrm{H}-5)$, and $8.66(1 \mathrm{H}, \mathrm{S}$, $\mathrm{H}-2)$.

\subsection{General procedure}

In this procedure, [CHCA] [DEA] and [HEMIM] [BF4] were used as hydrophilic task-specific ionic liquids (TSILs) to complex the ultra-trace amounts of $\mathrm{Ni}$ (II) and Cd (II) ions in Olive oil samples and extract them. The TUSA-DMP $\mu \mathrm{E}$ of metal ions was performed as follows: In a $100 \mathrm{~mL}$ glass centrifuge

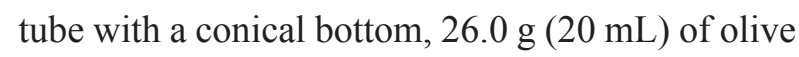
oil sample containing $\mathrm{Cd}$ and $\mathrm{Ni}$ ions was diluted with n-hexane up to $40 \mathrm{~mL}$. Then, the mixture of $0.25 \mathrm{~g}$ of the mentioned above TSILs and $0.5 \mathrm{~mL}$ of acetone (as a dispersive solvent) which was diluted with DW up to $5.0 \mathrm{~mL}$ was prepared and then, the $\mathrm{pH}$ adjusted between 2 to 10 by buffer solution. Afterwards, the mixture was injected rapidly into 40 $\mathrm{mL}$ of edible oil samples with HPLC autosampler syringe ( $5 \mathrm{~mL}$, gastight, CTC-PAL, Trajan, AUS) and stirred for $5 \mathrm{~min}$ at $85{ }^{\circ} \mathrm{C}$. The cloudy phases were then separated by centrifuging of the turbid solution for $4 \mathrm{~min}$ at $4000 \mathrm{rpm}\left(25^{\circ} \mathrm{C}\right)$. The $\mathrm{Cd} /$ Ni complexes were settled down at the bottom of the conical tube into droplets of TSILs. The upper phase of the sample (edible oil) was removed with a pipette, the metal complexes was back extracted from TSIL with $\mathrm{HNO}_{3}(0.2 \mathrm{~mL}, 0.5 \mathrm{M})$ and finally the concentration of $\mathrm{Ni}$ (II) and Cd (II) ions in the resulting solution was determined by AT-FAAS after dilution with deionized water up to $1 \mathrm{~mL}$. For validation, I $\mathrm{mL}$ of sample oils was digested with microwave accessory for 1 hour (UV, 5:1 mL; $\mathrm{HNO}_{3} / \mathrm{H}_{2} \mathrm{O}_{2}, 220^{\circ} \mathrm{C}$ ) and concentration of $\mathrm{Ni}$ and $\mathrm{Cd}$ ions determined by F-AAS/ET-AAS/ICP-MS (Figure 1).

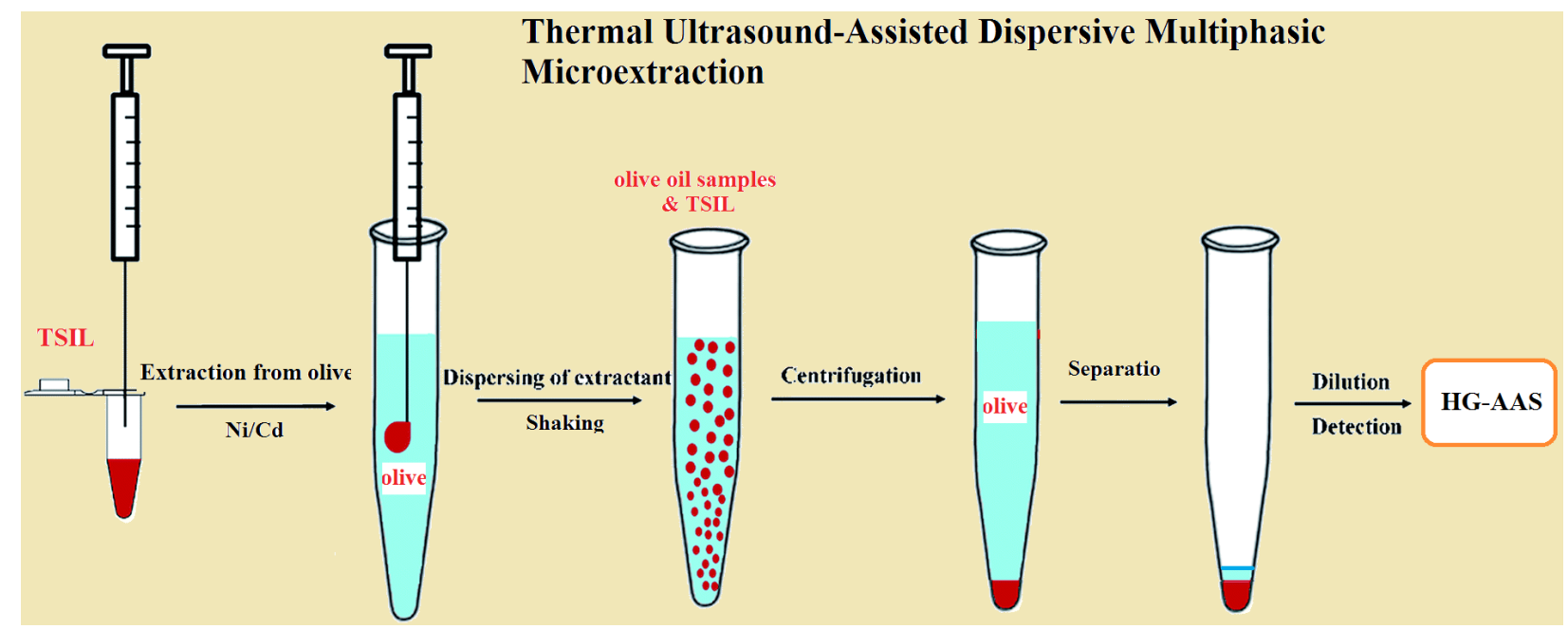

Fig. 1. General procedure for extraction of $\mathrm{Ni} / \mathrm{Cd}$ from olive oil by TUSA-DMP $\mu \mathrm{E}$ 


\section{Results and Discussion}

\subsection{Effect of sample $\mathrm{pH}$}

Complexation was strongly conditioned by the $\mathrm{pH}$ of the solutions. In the present work, the solution $\mathrm{pH}$ affected the extraction process through the functional group moieties of the TSIL. The influence of sample $\mathrm{pH}$ on the complex formation and the extraction of $\mathrm{Ni}$ (II) and Cd (II) ions with [CHCA] [DEA] and [HEMIM][BF4] TSILs was separately investigated at different $\mathrm{pH}$ values from 2 to 10 for $40 \mathrm{~mL}$ buffered diluted olive oil samples, according to the general procedure. The results were depicted in figures $2 \mathrm{a}$ and $2 \mathrm{~b}$. Obviously, the maximum extraction efficiencies for $\mathrm{Ni}$ (II) and $\mathrm{Cd}$
(II) ions were obtained with [CHCA] [DEA] TSIL in $\mathrm{pH}$ range of 6-8, and then the recoveries were decreased by increasing of $\mathrm{pH}$ (Fig. 2a). Whereas, by using [HEMIM][BF4] TSIL (Fig. 2b), the quantitative recoveries were less than $40-70 \%$ at $\mathrm{pH} 7.5-10$.

\subsection{Effect of sample volume}

The sample volume is one of the most important parameters to be studied by TUSA-DMP $\mu$ E method, since it determines the sensitivity and enhancement of the technique. The effect of sample volume was studied in the range of 5-40 mL for $5-100 \mu \mathrm{g} \mathrm{L}^{-1}$ of standard solution of $\mathrm{Ni}$ and $\mathrm{Cd}$ (Fig. 3).

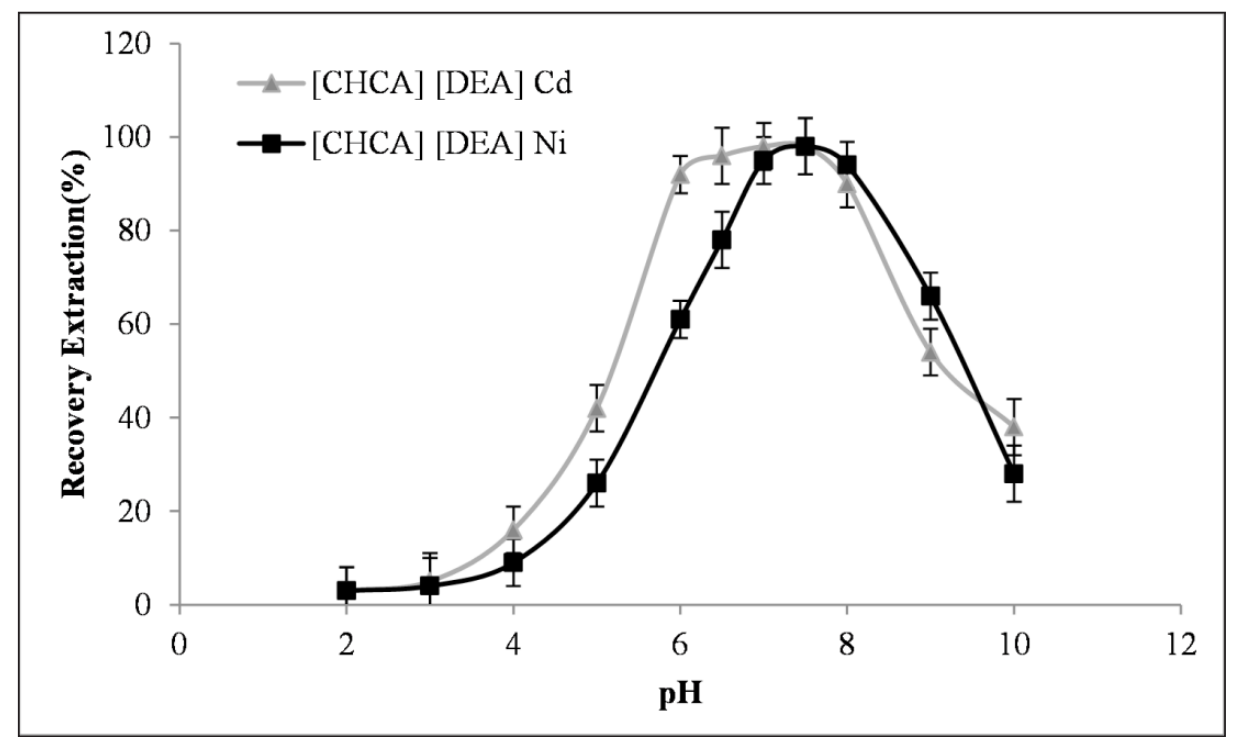

Fig. 2a. Effect of $\mathrm{pH}$ on extraction of $\mathrm{Ni}$ (II) and $\mathrm{Cd}$ (II) ions in olive oil with [CHCA] [DEA] by TUSA-DMP $\mu \mathrm{E}$

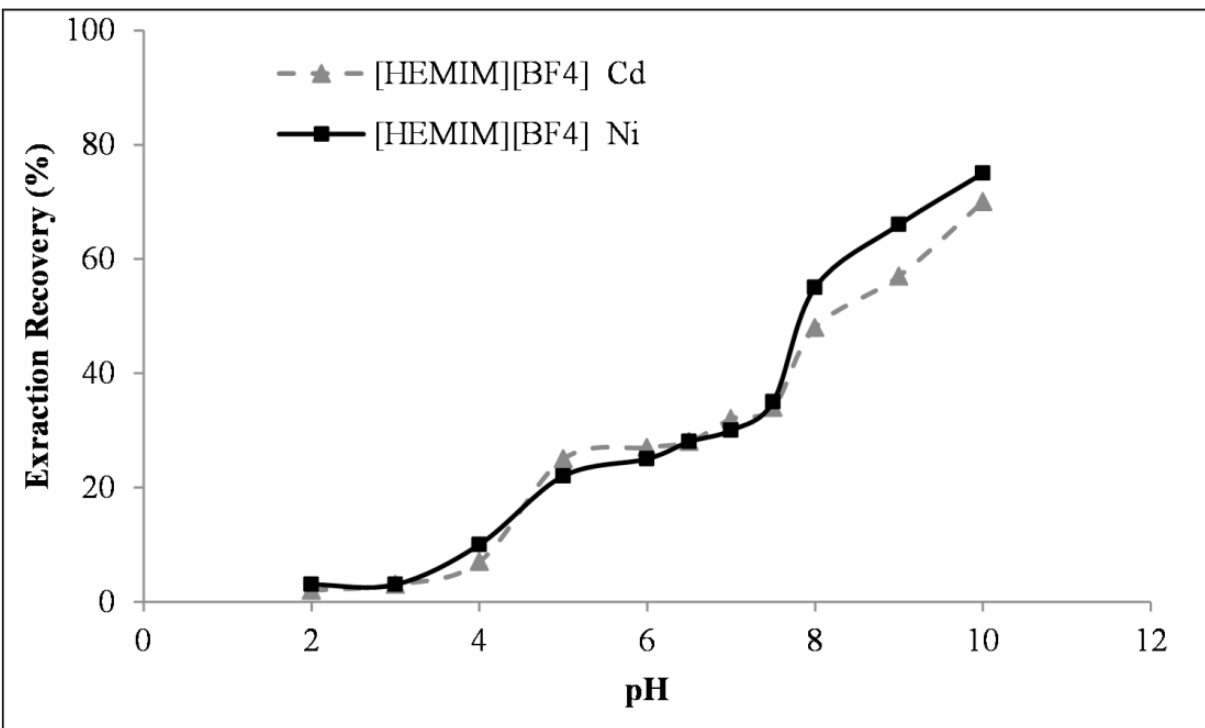

Fig. 2b. Effect of $\mathrm{pH}$ on extraction of $\mathrm{Ni}$ (II) and $\mathrm{Cd}$ (II) ions in olive oil with [CHCA] [DEA] by TUSA-DMP $\mu \mathrm{E}$. 


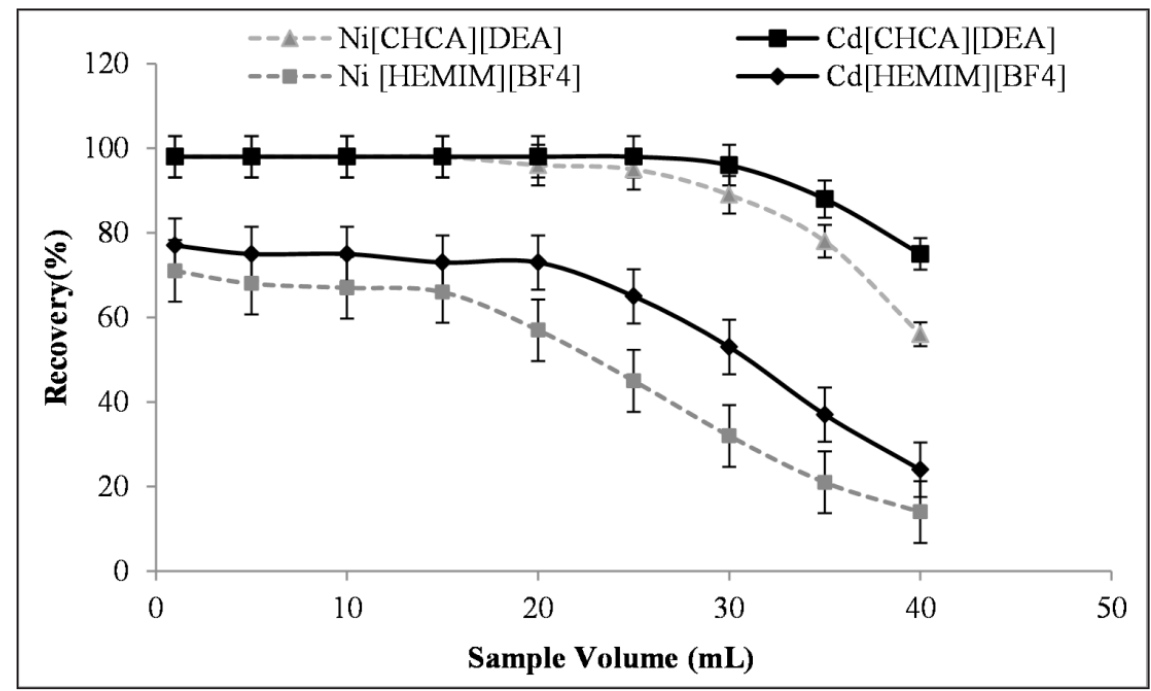

Fig. 3. Effect of sample volume on extraction of $\mathrm{Ni}$ (II) and $\mathrm{Cd}$ (II) ions in olive oil by TUSA-DMP $\mu$ E.

\subsection{Effect of TSIL amount on Ni and Cd extraction}

The amounts of ILs on the extraction efficiencies of $\mathrm{Ni} / \mathrm{Cd}$ in Olive oil by TUSA-DMP $\mu$ E method was studied and optimized. For this purposed, the range of 0.01-0.1 g of [CHCA] [DEA] and [HEMIM] [BF4] as a TSIL was used in human biological samples and standard solution containing; 5-100 $\mu \mathrm{g} \mathrm{L}^{-1}$ of $\mathrm{Ni}$ (II) and $\mathrm{Cd}$ (II) (Fig. 3). The results show that the quantitative recoveries were obtained with $20-40 \mathrm{mg}$ of [CHCA] [DEA] as a $98 \%$ recovery. Therefore, in order to achieve a suitable preconcentration, $50 \mathrm{mg}$ of [CHCA] [DEA] was chosen as optimum leading to a final IL for blood/urine and standard solution analysis. Also, the effect of IL used on the recovery efficiencies of $\mathrm{Ni} / \mathrm{Cd}$ ions with TSIL of [HEMIM][BF4] was investigated by TUSA-DMP $\mu \mathrm{E}$ method. The results showed us, the maximum recoveries of $\mathrm{Ni} / \mathrm{Cd}$ in olive oils were less than $64 \%$ by using [HEMIM][BF4], therefore the [HEMIM][BF4] had lower recovery as compared to [CHCA] [DEA]. Moreover, by increasing the ultra-sonication time up to $60 \mathrm{~min}$ and $150 \mathrm{mg}$ of [HEMIM][BF4], the almost $73 \%$ of $\mathrm{Ni} / \mathrm{Cd}$ ions from olive oils can be extracted by [HEMIM][BF4] in standard solution (Fig. 4). So, the recovery extraction of ions with [HEMIM][BF4] cannot be increased by long time or amount of IL.

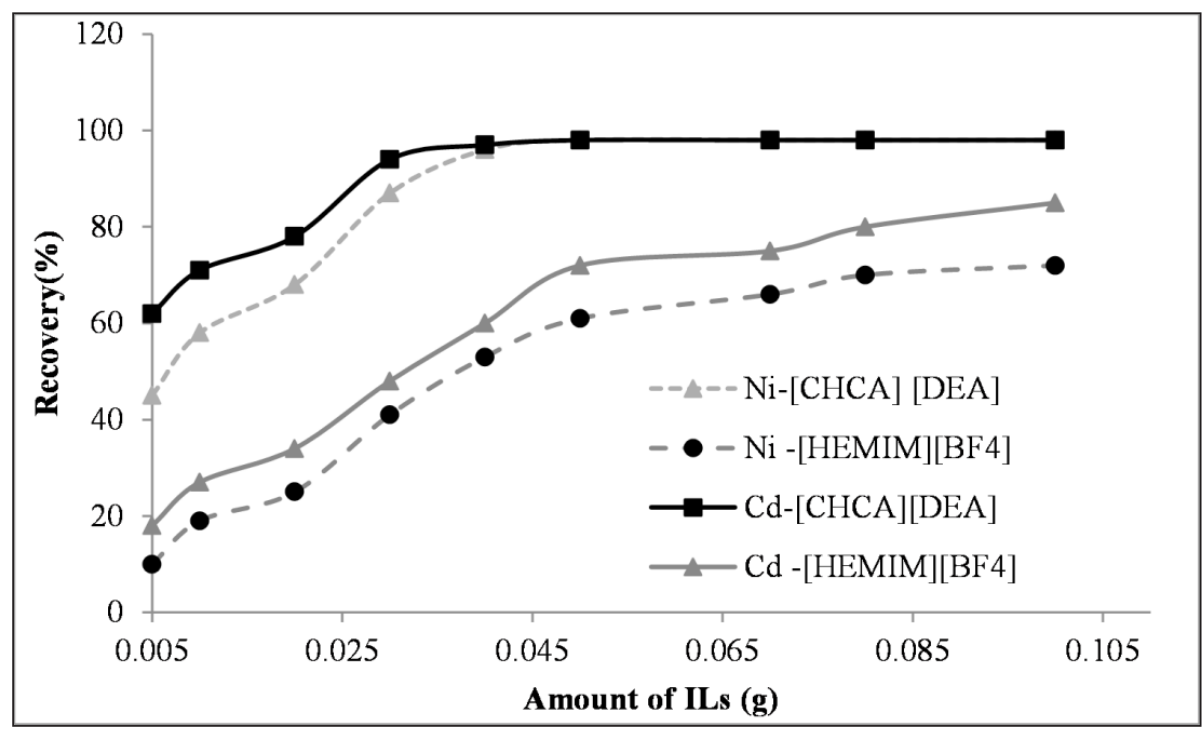

Fig. 4. Effect of amount of TSILs on extraction of Ni (II) and Cd (II) ions in olive oil by TUSA-DMP $\mu \mathrm{E}$ 


\subsection{Effect of ultra-sonication time for $\mathrm{Ni}$ and $\mathrm{Cd}$ extraction}

The ultra-sonication time during the extraction process can improve the extraction recovery since it enhances the complexation of $\mathrm{Ni} / \mathrm{Cd}$ ions to TSIL. Based on procedure, kind of TSILs are the most important factors for sonication time by TUSA-DMP $\mu \mathrm{E}$ method. Therefore, the effect of sonication type, shaker tube or ultrasound bath, on the recovery efficiencies of $\mathrm{Ni} / \mathrm{Cd}$ ions in olive oils was examined by [CHCA] [DEA] and [HEMIM] [BF4]. The results showed, the maximum recovery was obtained using sonication at $5 \mathrm{~min}$. The optimization of sonication time increased the extraction recovery and decreased the time and IL mass. This fact can be related to the large contact area between dispersion of TSILs with olive oil samples. In this study, ultrasound assisted extraction times ranging from 1 to $25 \mathrm{~min}$ were evaluated. Therefore, the ultrasonic time of $5 \mathrm{~min}$ was selected as optimum time (Fig. 5).

\subsection{Interference study}

The determination of $\mathrm{Ni} / \mathrm{Cd}$ ions in different olive oil samples in the presence of interfering matrix ions was examined. In order to get the acceptable analytical technique by TUSA-DMP $\mu \mathrm{E}$ procedure, various interfering cations such as; $\mathrm{Na}^{+}, \mathrm{K}^{+}, \mathrm{V}^{3+}$, $\mathrm{Cu}^{2+}, \mathrm{Zn}^{2+}, \mathrm{Al}^{3+}, \mathrm{Co}^{2+}, \mathrm{Cr}^{3+}, \mathrm{Hg}^{2+}, \mathrm{As}^{3+}, \mathrm{Mn}^{2+}$ and anions, $\mathrm{SO}_{3}{ }^{2-}, \mathrm{NO} 3-, \mathrm{Cl}^{-}, \mathrm{F}^{-}, \mathrm{PO}_{4}{ }^{3-}\left(1-3 \mathrm{mgL}^{-}\right.$ $\left.{ }^{1}\right)$ were added individually to real olive oil and standard solutions containing 5-100 $\mu \mathrm{gL}^{-1}$ of $\mathrm{Ni}^{2+}$ and $\mathrm{Cd}^{2+}$ in optimized conditions. Interfering ions concentration causing less than $\pm 5 \%$ deviation in the recovery of $\mathrm{Ni}(\mathrm{II})$ and $\mathrm{Cd}(\mathrm{II})$ was considered as the tolerance limit. Based on the results, the presence of interfering ions has no considerable effect on the recovery efficiencies of $\mathrm{Ni}(\mathrm{II})$ and $\mathrm{Cd}(\mathrm{II})$ in olive oil samples.

\subsection{Effect of Temperature on Ni and Cd extraction}

The temperature has a critical role in extraction recovery of $\mathrm{Ni}(\mathrm{II})$ and $\mathrm{Cd}(\mathrm{II})$ in olive oil samples by TSILs. As evaluation of TSILs, the effect of temperature was studied and optimized between 20-90 ${ }^{\circ} \mathrm{C}$. The results showed us, the extraction efficiency of $\mathrm{Ni}(\mathrm{II})$ and $\mathrm{Cd}(\mathrm{II})$ by [CHCA] [DEA] and [HEMIM] [BF4]was depended to temperature. The results showed us, the optimized temperature was obtained between $40-60{ }^{\circ} \mathrm{C}$. In optimized temperature, the extraction ions in olive oils with [CHCA] [DEA] was more than [HEMIM][BF4].

\subsection{Effect of mineral acids on the back-extraction ions}

Because of high viscosity of TSILs, the direct injection of ILs into AT-FAAS is not possible. So, the Ni and Cd ions back extracted from TSILs with

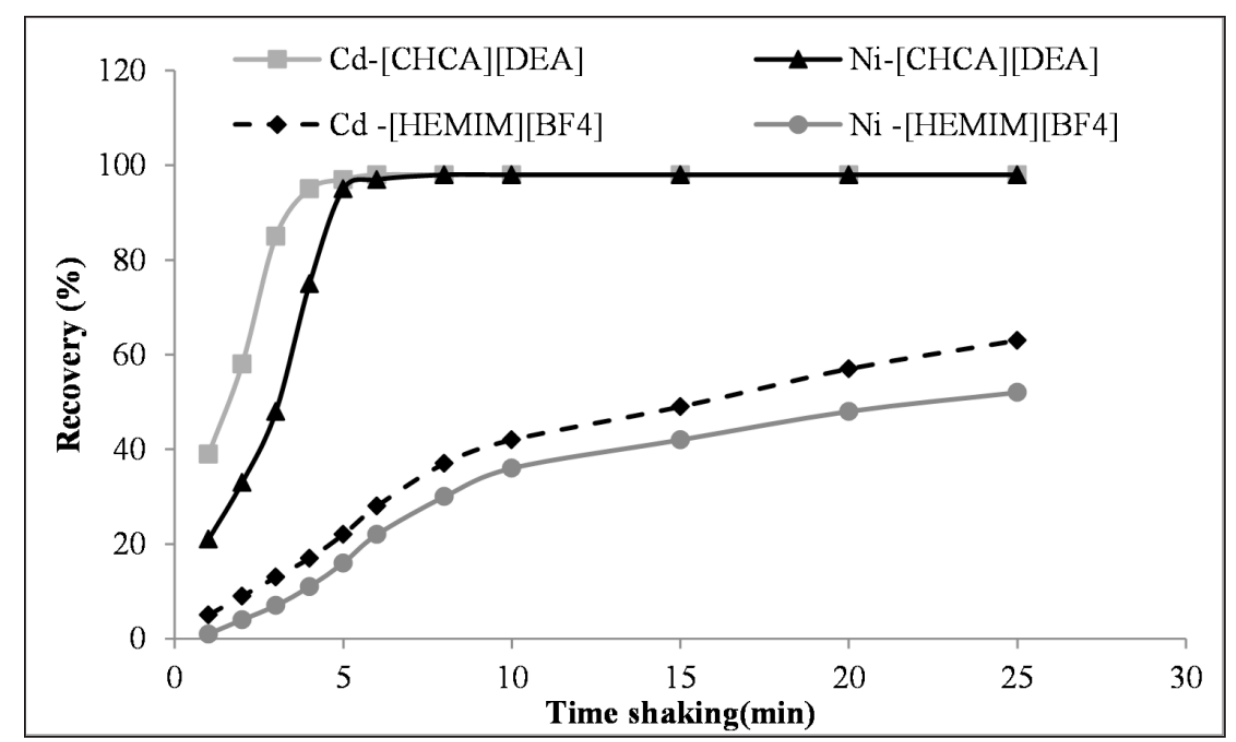

Fig. 5. Effect of shaking time on extraction of $\mathrm{Ni}$ (II) and $\mathrm{Cd}$ (II) ions in olive oil by TUSA-DMP $\mu \mathrm{E}$ 
a mineral acidic solution. Decreasing the $\mathrm{pH}$ leads to dissociation and releasing of $\mathrm{Ni}(\mathrm{II})$ ions into the aqueous phase. Different mineral acids such as $\mathrm{HCl}, \mathrm{HNO}_{3}, \mathrm{CH}_{3} \mathrm{COOH}$ and $\mathrm{H}_{2} \mathrm{SO}_{4}(0.1-0.5 \mathrm{M})$ were studied for $\mathrm{Ni} / \mathrm{Cd}$ back-extraction from the TSILs. The research showed that $0.1 \mathrm{~mL}$ of $\mathrm{HNO}_{3}$ $(0.5 \mathrm{M})$ quantitatively back-extracted $\mathrm{Ni} / \mathrm{Cd}$ ions from the olive oil samples before diluted with DW up to $1 \mathrm{~mL}$.

\subsection{Validation of Method}

The analytical characteristics of the developed TUSA-DMP $\mu$ E method at the optimum conditions were shown in table 1. After sample preparation, $\mathrm{Ni}$ / Cd in olive oils and standard samples was determined by proposed method. The olive oils samples as a real sample was used for determination of $\mathrm{Ni} / \mathrm{Cd}$ as the average of three separate determinations. The accuracy of the results was verified by analyzing the spiked samples with known concentration of $\mathrm{Ni} / \mathrm{Cd}$ (II) in olive oils samples (Tables 2). Based on the obtained results, a good agreement was obtained between the added and measured $\mathrm{Ni} / \mathrm{Cd}$ amount, which confirms the accuracy of the procedure and its independence from the matrix effects. The recoveries of spiked samples demonstrated that the developed method was satisfactory for $\mathrm{Ni} / \mathrm{Cd}$ analysis. In order to validate the method described, certified reference materials in olive oils (CRM, A-D) which was determined with ET-AAS after microwave digestion with pure acid and $\mathrm{H}_{2} \mathrm{O}_{2}$, were analyzed by proposed method (Table 3 ). Analytical results of the CRM samples were satisfactorily in agreement with the certified values. Moreover, a good agreement was obtained between added and found values of the $\mathrm{Ni} / \mathrm{Cd}$ ions in spiked samples by CRM samples.

\section{Conclusions}

A novel, reliable and efficient method was used for preconcentration, separation and determination of trace $\mathrm{Ni} / \mathrm{Cd}$ in olive oil samples by TUSA$\mathrm{DMP} \mu \mathrm{E}$ procedure. The proposed method was developed based on hydrophilic TSILs $(\alpha-$ Cyano-4-hydroxycinnamic acid diethylamine; [CHCA] [DEA] and 1-(2-Hydroxyethyl)-3methylimidazolium Tetrafluoroborate; [HEMIM] [BF4]) as a complexing and extracting solvent which was coupled by AT-FAAS technique. Finally, the newly developed method was low interference,

Table 1. Analytical characteristics of the developed TUSA-DMP $\mu \mathrm{E}$ method at the optimum conditions by [CHCA] [DEA].

\begin{tabular}{ccccccc}
\hline Metal ions & $\begin{array}{c}\text { Sample volume } \\
(\mathrm{mL})\end{array}$ & $\begin{array}{c}\text { Linear range } \\
(\mu \mathrm{g} \mathrm{L})\end{array}$ & $\begin{array}{c}\text { Regression } \\
\text { coefficient }\left(\mathrm{R}^{2}\right)\end{array}$ & $\begin{array}{c}\mathrm{LOD}^{\mathrm{a}} \\
(\mathrm{n}=10)\left(\mu \mathrm{g} \mathrm{L}^{-1}\right)\end{array}$ & $\begin{array}{c}\mathrm{RSD}^{\mathrm{b}} \\
(\mathrm{n}=10)(\%)\end{array}$ & $\mathrm{PF}^{\mathrm{c}}$ \\
\hline $\mathrm{Cd}^{2+}$ & 20 & $2.7-92$ & 0.9996 & 0.6 & $4.4 \%$ & 19.6 \\
\hline $\mathrm{Ni}^{2+}$ & 20 & $5.0-415$ & 0.9998 & 1.3 & $5.1 \%$ & 19.3 \\
\hline
\end{tabular}

${ }^{\mathrm{a}}$ Limit of detection, ${ }^{\mathrm{b}}$ Relative standard deviation, ${ }^{\mathrm{c}}$ Preconcentration factor

Table 2. Analytical results for determination of analytes in spiked olive oil samples.

\begin{tabular}{|c|c|c|c|c|c|c|c|c|}
\hline \multirow[t]{2}{*}{ Sample } & \multicolumn{2}{|c|}{ Added $\left(\mu g L^{-1}\right)$} & \multicolumn{2}{|c|}{ Found a $\left(\mu \mathrm{g} \mathrm{L}^{-1}\right)$} & \multicolumn{2}{|c|}{$\operatorname{RSD}^{\mathrm{b}}(\%)$} & \multicolumn{2}{|c|}{ Recovery (\%) } \\
\hline & $\mathrm{Cd}^{2+}$ & $\mathrm{Ni}^{2+}$ & $\mathrm{Cd}^{2+}$ & $\mathrm{Ni}^{2+}$ & $\mathrm{Cd}^{2+}$ & $\mathrm{Ni}^{2+}$ & $\mathrm{Cd}^{2+}$ & $\mathrm{Ni}^{2+}$ \\
\hline \multirow[t]{2}{*}{ Olive 1} & ----- & ----- & 3.6 & 65.7 & 4.2 & 5.7 & ----- & ----- \\
\hline & 5.0 & 50.0 & 8.4 & 114.8 & 5.3 & 4.7 & 0.96 & 98.2 \\
\hline \multirow[t]{2}{*}{ Olive 2} & ----- & ----- & 18.5 & 98.4 & 3.9 & 4.8 & ----- & ----- \\
\hline & 20.0 & 100.0 & 39.1 & 197.7 & 4.5 & 5.1 & 103 & 99.3 \\
\hline \multirow[t]{2}{*}{ Olive 3} & ----- & ----- & 2.5 & 32.2 & 4.9 & 5.3 & ----- & ----- \\
\hline & 2.0 & 30.0 & 4.4 & 61.4 & 5.7 & 5.4 & 95.0 & 97.4 \\
\hline \multirow[t]{2}{*}{ Olive 4} & ----- & ----- & 22.6 & 45.8 & 5.4 & 5.3 & ----- & ----- \\
\hline & 20.0 & 50.0 & 41.8 & 95.9 & 4.4 & 4.7 & 96.0 & 102 \\
\hline
\end{tabular}

${ }^{\mathrm{a}}$ Mean of three determinations \pm confidence interval $(\mathrm{P}=0.95, \mathrm{n}=5),{ }^{\mathrm{b}}$ Relative standard deviation. 
Table 3. Validation of developed TUSA-DMP $\mu E$ method with Standard Reference Material (CRM).

\begin{tabular}{|c|c|c|c|c|c|c|c|c|}
\hline \multirow[t]{2}{*}{ sample } & \multicolumn{2}{|c|}{$\begin{array}{c}\text { Certified a } \\
\left(\mu g \mathrm{~L}^{-1}\right)\end{array}$} & \multicolumn{2}{|c|}{$\begin{array}{c}\text { Added } \\
\left(\mu g L^{-1}\right)\end{array}$} & \multicolumn{2}{|c|}{$\begin{array}{l}\text { Found }^{b} \\
\left(\mu g L^{-1}\right)\end{array}$} & \multicolumn{2}{|c|}{$\begin{array}{c}\text { Recovery } \\
(\%)\end{array}$} \\
\hline & $\mathrm{Cd}(\mathrm{II})$ & Ni(II) & $\mathrm{Cd}(\mathrm{II})$ & $\mathrm{Ni}(\mathrm{II})$ & $\mathrm{Cd}(\mathrm{II})$ & $\mathrm{Ni}(\mathrm{II})$ & $\mathrm{Cd}(\mathrm{II})$ & $\mathrm{Ni}(\mathrm{II})$ \\
\hline A & 4.5 & 10.5 & 5 & 10 & 9.3 & 19.9 & 97.9 & 97.1 \\
\hline B & 12.8 & 45.6 & 10 & 50 & 22.1 & 94.4 & 96.9 & 98.7 \\
\hline $\mathrm{C}$ & 55.2 & 117.9 & 50 & 100 & 99.9 & 209.7 & 94.9 & 96.2 \\
\hline $\mathrm{D}$ & 88.6 & 267.9 & 100 & 200 & 191.1 & 460.2 & 101.0 & 98.3 \\
\hline
\end{tabular}

${ }^{a}$ Certified by ETAAS after digestion with micro wave of oils

${ }^{\mathrm{b}}$ Mean of three determinations \pm confidence interval $(\mathrm{P}=0.95, \mathrm{n}=5)$,

easy usage for sample preparation in olive oil samples and also provides low LOD, and RSD values as well as good $\mathrm{PF}$ values and quantitative recoveries for $\mathrm{Ni} / \mathrm{Cd}$ extraction in difficulty olive oil matrix ( $>95 \%)$. Therefore, the proposed method can be considered as simple and applied sample preparation techniques with TSILs for $\mathrm{Ni} / \mathrm{Cd}$ separation / determination in olive oil samples by AT-FAAS.

\section{Acknowledgements}

The authors wish to thank the Iranian Research Institute of Petroleum Industry (RIPI) for this work (No grant or fund by RIPI).

\section{References}

[1] O. Acar, Evaluation of cadmium, lead, copper, iron and zinc in Turkish dietary vegetable oils and olives using electrothermal and flame atomic absorption spectrometry, grasas y aceites, 63 (2012) 383-393.

[2] A. Palizban, A. Badii, G. Asghari, H. MardaniNafchi, Lead and cadmium contamination in seeds and oils of Brassica napus L and Carthamus tinctorius grown in Isfahan Province/Iran, Iranian J. Toxicol., 8 (2015) 1196-1202.

[3] E.K. Baran, S.B. Yaşar, Zinc and nickel determination in liquid edible oils by FAAS after the extraction, Eur. j. lipid sci. technol., 114 (2012) 1320-1326.

[4] K. Bakkali, N.R. Martos, B. Souhail, E. Ballesteros, Determination of heavy metal content in vegetables and oils from Spain and Morocco by inductively coupled plasma mass spectrometry, Anal. Lett., 45 (2012) 907-919.

[5] M.Y. Aşci, A. Efendioglu, B. Bati, Solid phase extraction of cadmium in edible oils using zinc piperazinedithiocarbamate and its determination by flame atomic absorption spectrometry, Turkish J. Chem., 32 (2008) 431-440.

[6] C. Onyema, K. Ibe, Effects of Refining Processes on the Physicochemical Properties of Some Selected Vegetable Oils, Am. Chem. Sci. J., 12 (2016) 1-7.

[7] S.U. Okorie, C.N. Nwachukwu, Comparative Evaluation Of Quality Characteristics Of Oils Extracted From Some Selected Legumes And A Cereal, IOSR J. Environ. Sci., Toxicol. Food Technol., 8 (2014) 66-69.

[8] H. Well, Agency for Toxic Substances and Disease Registry (ATSDR), 2015.

[9] M. Hezbullah, S. Sultana, S. Chakraborty, M. Patwary, Heavy metal contamination of food in a developing country like Bangladesh: An emerging threat to food safety, J. Toxicol. Environ. Health Sci., 8 (2016) 1-5.

[10] F. Zhu, W. Fan, X. Wang, L. Qu, S. Yao, Health risk assessment of eight heavy metals in nine varieties of edible vegetable oils consumed in China, Food chem. toxicol., 49 (2011) 3081-3085.

[11] D. Mendil, Ö.D. Uluözlü, M. Tüzen, M. Soylak, Investigation of the levels of some element in edible oil samples produced in Turkey by atomic absorption spectrometry, J. Hazard. Mater., 165 (2009) 724-728.

[12] M. Zeiner, I. Steffan, I.J. Cindric, Determination of trace elements in olive oil by ICP-AES and ETA-AAS: A pilot study on the geographical characterization, Microchem. J., 81 (2005) 171176.

[13] I.J. Cindric, M. Zeiner, I. Steffan, Trace elemental characterization of edible oils by ICP-AES and GFAAS, Microch. J., 85 (2007) 136-139.

[14] E. Llorent-Martínez, P. Ortega-Barrales, M. Fernández-de Córdova, A. Domínguez-Vidal, A. Ruiz-Medina, Investigation by ICP-MS of trace 
element levels in vegetable edible oils produced in Spain, Food Chem., 127 (2011) 1257-1262.

[15] T.G. Díaz, A. Guiberteau, M.L. Soto, J. Ortiz, Determination of copper with 5, 5-dimethylcyclohexane-1, 2, 3-trione 1, 2-dioxime 3-thiosemicarbazone in olive oils by adsorptive stripping square wave voltammetry, Food Chem., 96 (2006) 156-162.

[16] F. Tokay, S. Bağdat, Spectrometric determination of iron and copper in vegetable oils after separation with Schiff base impregnated silica gel column: A simple approach for eliminating the high organic matrix, Int. j. food sci. technol., 50 (2015) 26942699.

[17] F. Tokay, S. Bağdat, Determination of iron and copper in edible oils by flame atomic absorption spectrometry after liquid-liquid extraction, J. Am. Oil Chem. Soc., 92 (2015) 317-322.

[18] M. Rezaee, Y. Assadi, M.-R.M. Hosseini, E. Aghaee, F. Ahmadi, S. Berijani, Determination of organic compounds in water using dispersive liquid-liquid microextraction, J. Chromatogr. A, 1116 (2006) 1-9.

[19] I. López-García, Y. Vicente-Martínez, M. Hernández-Córdoba, Determination of cadmium and lead in edible oils by electrothermal atomic absorption spectrometry after reverse dispersive liquid-liquid microextraction, Talanta, 124 (2014) 106-110.

[20] H. Shirkhanloo, A. Khaligh, H.Z. Mousavi, M.M. Eskandari, A.A. Miran-Beigi, Ultra-trace arsenic and mercury speciation and determination in blood samples by ionic liquid-based dispersive liquid-liquid microextraction combined with flow injection-hydride generation/cold vapor atomic absorption spectroscopy, Chem. Papers, 69 (2015) 779-790.

[21] H. Shirkhanloo, M. Ghazaghi, H.Z. Mousavi, Cadmium determination in human biological samples based on trioctylmethyl ammonium thiosalicylate as a task-specific ionic liquid by dispersive liquid-liquid microextraction method, J. Mol. Liq., 218 (2016) 478-483.

[22] J. Werner, Determination of metal ions in tea samples using task $\square$ specific ionic liquid $\square$ based ultrasound $\square$ assisted dispersive liquid-liquid microextraction coupled to liquid chromatography with ultraviolet detection, J. sep. sci., 39 (2016)
1411-1417.

[23] S. Sadeghi, A.Z. Moghaddam, Task-specific ionic liquid based in situ dispersive liquid-liquid microextraction for the sequential extraction and determination of chromium species: optimization by experimental design, RSC Adv., 5 (2015) 60621-60629.

[24] N. Khan, T.G. Kazi, H.I. Afridi, M.B. Arain, Determination of cadmium in human serum and blood samples after dispersive liquid-liquid microextraction using a task specific ionic liquid, Anal. Lett., (2017).

[25] M.J. Trujillo-Rodríguez, P. Rocío-Bautista, V. Pino, A.M. Afonso, Ionic liquids in dispersive liquidliquid microextraction, TrAC Trends in Anal. Chem., 51 (2013) 87-106.

[26] Q. Zhou, H. Bai, G. Xie, J. Xiao, Temperaturecontrolled ionic liquid dispersive liquid phase micro-extraction, J. Chromatogr. A, 1177 (2008) 43-49.

[27] Q. Zhou, X. Zhang, J. Xiao, Ultrasound-assisted ionic liquid dispersive liquid-phase microextraction: A novel approach for the sensitive determination of aromatic amines in water samples, J. Chromatogr. A, 1216 (2009) 4361-4365.

[28] J.Zhang, H. Gao, B. Peng, S. Li, Z. Zhou, Comparison of the performance of conventional, temperaturecontrolled, and ultrasound-assisted ionic liquid dispersive liquid-liquid microextraction combined with high-performance liquid chromatography in analyzing pyrethroid pesticides in honey samples, J. Chromatogr. A, 1218 (2011) 6621-6629. 